\title{
Bioactive Plant Extracts an Alternate to Chemicals for Management of Armyworm Infesting Oats
}

\author{
Ritesh Kumar ${ }^{1}$, Ishtiyaq Ahad ${ }^{1 *}$, Aijaz Ahmad Sheikh ${ }^{1}$, \\ Abid Showkat ${ }^{1}$, Uzma Arifie ${ }^{1}$ and Stanzin Dorjey $^{2}$ \\ ${ }^{1}$ Division of Entomology, ${ }^{2}$ Division of Plant Pathology, Sher-e-Kashmir University of \\ Agricultural Sciences and Technology of Kashmir, Wadura Sopore, 193201, Kashmir, India \\ *Corresponding author
}

\section{A B S T R A C T}

Keywords

Oats, Mythimna separata, Mortality, Green leaf extract.

Article Info

Accepted:

04 October 2017

Available Online:

10 December 2017
Experiment was carried out in the field at the Faculty of Agriculture, Wadura, North Kashmir during 2015-16 under free choice conditions to evaluate the efficacy of Green leaf extracts against Mythimna separate on oats crop. The results revealed that dichlorvos showed significant results in increase in pest mortality 48.15, 59.11, 69.23 and 46.16 per cent after 1,3 , 5 and 7 days after treatment (DAT), respectively with 89.34 per cent increase in the mortality over control. This was followed by NSKE 39.90, 49.18, 59.02 and 38.53 per cent after 1, 3, 5 and 7 DAS, respectively with 87.28 per cent increase in the mortality over control. Among the botanicals NSKE was found to be most effective followed by Artemisia annua however, it was found least in case of green leaf extract of walnut.

\section{Introduction}

Oats rank sixth in the world cereal production statistics following wheat, maize, rice, barley and sorghum. It is an important livestock feed and is a good source of protein, fiber and minerals. This crop is considered to be a rich source of protein, equal to meat, milk, and egg protein. As food oats are mostly preferred in breakfast, moreover it is viewed by consumers as one of the wholesome, healthiest, natural food with the result there is rising global food demand for oats. Out of cereals, the highest amounts of $\beta$-glycan are found in barley and oats grains (Ahmad and Zaffar, 2014). It is cultivated in Punjab,
Haryana, West Bengal, Jammu \& Kashmir, Himachal Pradesh, Uttar Pradesh, Madhya Pradesh, Rajasthan and Maharashtra. The total area covered under oats cultivation in the country is about 5 lakh ha. The crop occupies maximum area in Uttar Pradesh (34 per cent), followed by Punjab (20 per cent), Bihar (16 per cent), Haryana (9 per cent) and Madhya Pradesh (6 per cent) (Pandey and Roy, 2011). Various arthropods and nematodes cause damage to oats (Avena sativa L. and $A$. byzantino K.) plants throughout their life and no stage of the crop is free from damage. Crops can be affected from the seedling stage 
until the grain is harvested. Pests of oats are either polyphagous (damaging a wide range of plants) or oligophagous (feeding on only a few plant species) and it is very rare, any insect found to be monophagous to oats crop. Hundreds of arthropod species feed on oats cultivated in the USA and other countries. Low infestations of certain pests in cereals may stimulate growth and tillers, and actually increase yields (Southwood and Norton, 1973).The armyworm is one of the most destructive insects infesting oats. It destroys oats in some areas almost every year. Outbreaks are frequently local and sporadic, but occasionally high populations have infested large sections of the eastern USA and Canada (Walkden, 1950). Damage to oats in 1954 was estimated to be over $\$ 5$ million (USA); an estimated $\$ 12$ million (USA) loss was prevented with insecticides. In Jammu and Kashmir Lone et al., (2009) reported army worm Mythimna separate major pest in the state which caused heavy losses in the oats which is grown only for fodder purpose.

Adverse effects of synthetic pesticides on humans are caused by pesticides residues left on crops when they are eaten. These residues can negatively affect human health through chronic illnesses such as cancer and sterility (Bale et al., 2008). Adverse effects of the application of pesticides on the environment can be summarized as: biodiversity loss, water contamination, disruption of food chains and soil degradation.

Bioactive plant extracts as an alternative to synthetic pesticides, although botanicals pesticides have been used for thousands of years against insect pests. These provide a valuable source of active chemicals such as alkaloids, terpenoids, cucurbitacin, glycosides, flavonoids and other compound that have been used as toxins against several insect pests which affect commercial crops (Koul and Walia, 2009). The use of these biologically active mixtures is usually safer to humans and the environment than conventional pesticides, with minimal residual effects and also with least development of resistance against pests. Therefore the use of plant pesticides has been recommended ever more as a suitable alternative of plant protection with minimum negative risks. Keeping in view the above facts it becomes imperative to study the bioactive plant extracts for management of the $M$. separata on oats.

\section{Materials and Methods}

An experiment was carried out to assess the efficacy of Green leaf extracts viz. Artemisia (Artemisia annua L.), Anthemis cotula, Datura (Datura stramonium L.), Walnut (Juglansregia), NSKE, and Rhizome extract of Ginger (Zingiber officinale) @ 5\% were evaluated against the $M$. separata on oats crop at the Faculty of Agriculture, Wadura, SKUAST-Kashmir during 2015-16. Dichlorvos 76 EC @ 0.076\% and sterile water are kept as positive and negative control respectively. Variety Sabzar was sown on $1^{\text {st }}$ November 2015 for this purpose. The experiment was laid out in a Randomized Complete Block Design with eight treatments and three replications, in a field measuring about plot size was $3 \times 4 \mathrm{~m}^{2}$ (Total=24 plot) and spacing $22.5 \mathrm{~cm}$.

\section{Preparation of plant extracts}

Plant parts from different test plants were collected, washed with water to remove dirt and chopped into small pieces, then grinded using clean water in the ratio of 50 gm plant material in one liter of water to get $5 \%$ solution and filtered through double folded muslin cloth to prevent fiber particles from blocking the spray nozzle. Small quantity of starch and soap solution was also added to improve their rain fastness and better 
distribution on crop. The treatments were imposed using a Knapsack sprayer. The death of larvae population per $\mathrm{cm}^{2}$ was recorded after spray at 1, 3, 5 and 7 days after treatment. Percent mortality of larvae over negative control was calculated. Data collected from the experimental site was subjected to standard statistical procedure using standard statistical procedures (Gomez and Gomez, 1984). Botanicals and insecticide was applied in the evening to escape the effect of sunlight on chemicals. Per cent mortality was calculated as:

$$
\text { Pre count - Post count }
$$

Per cent mortality $=$----------------- x 100
Pre count

Where,

Pre count $=$ Number of live larvae before treatments

Post count $=$ Number of live larvae after treatment

Similarly, increase mortality over control was calculated as:

Treated - control

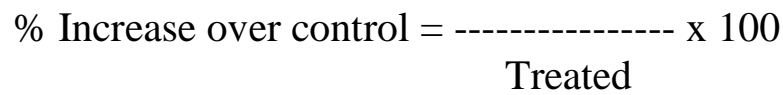

\section{Results and Discussion}

Field efficacy of different plant extracts was evaluated against $M$. separata infesting oats under field conditions (Table 1). Data obtained on this aspect revealed that at the time of initiation of experiment, the population of $M$. separate varied from plant to plant. Observations recorded on 1, 3, 5 and 7 days after treatment (DAT) revealed among the tested botanical insecticide @ 5\% level of concentration, and DDVP76 EC @ $0.076 \%$ were evaluated against $M$. separata. Present studies revealed that among different plant extracts evaluated, highest control was recorded in case of NSKE@5\% against $M$. Separate with highest mean percent mortality of $46.65 \%$, followed by $A$. annua with $38.49 \%$ after 7 days of treatments. The remaining extracts with decreasing order of efficacy were A. cotula (80.71) > Datura (79.17) > Ginger (75.64) > Walnut (69.82) (Table 1 and Fig. 1). The results of the present study were in conformity with the findings of Hellpap (1984) who reported that extract of neem seed kernel when mixed with rearing diet caused complete mortality of 4-10 days old fall armyworm larvae. The better results of NSKE may be due to antifeedant or repellent property and this is in line with the observation of neem plant extracts deter insects from feeding. The antifeedant and anti-molting effect of neem crude extract were evaluated against various lepidopterans and comparable results were obtained. This insect order has been reported to be particularly sensitive to neem products (Calvo and Molina, 2003). Schmutterer and Singh (1995) also found that azadirachtin as the main active compound, meliantriol, salanin, Nimbidin and nimbin present in neem seeds. These compounds suppress the leaf eating caterpillar populations. Azadirachtin acts as ecdyson-blockers or substances that can inhibit the function of hormone-ecdyson in the process of insect metamorphosis. Insects will be disturbed in the process of moulting, from egg to larva, from larva into pupa, or from the pupa becomes an adult. Insects will be dead if it fails in the process of metamorphosis. Therefore, the use of neem as a botanical insecticide does not directly result in the death of the pest. Based on this research, the death of the larvae occurred in 57 days after application (Indiati et al., 2013). Pests are sprayed with neem seed powder became lethargic and its ability to damage plants dropped significantly, because the pests in sickness. Meliantriol acts as a repellent, causing crop pests are reluctant to approach. 
Plants that have been sprayed with neem seed extract, less favored by insect pests, so that the plants suffered low pest attack. Further, in the present study all other treatments also significantly reduced the $M$. separata population over control. The results are in agreement with the findings of Khosravi et al., (2010) reported that A. аппиа extract affected the nutritional indices and also showed antifeedant activities on Glyphodes pyloalis Walker. The essential oil of $A$. judaica $\mathrm{L}$. has been demonstrated to possess insecticidal activity and repellence against several insects, such as Callosobruchus maculatus (Fab.) and Sitophilus oryzae L. (Abd-Elhady, 2012).

Table.1 Efficacy of various botanicals and DDVP against M. Separate

\begin{tabular}{|c|c|c|c|c|c|c|}
\hline \multirow[b]{2}{*}{ Treatments } & \multicolumn{5}{|c|}{ Per cent mortality } & \multirow{2}{*}{$\begin{array}{c}\text { Increase } \\
\text { over } \\
\text { control } \%\end{array}$} \\
\hline & $\begin{array}{c}1 \\
\text { DAT }\end{array}$ & $\begin{array}{c}3 \\
\text { DAT }\end{array}$ & $\begin{array}{c}5 \\
\text { DAT }\end{array}$ & $\begin{array}{c}7 \\
\text { DAT }\end{array}$ & Mean & \\
\hline $\begin{array}{l}\text { GLE } \\
\text { Artemisiaannua 5\% }\end{array}$ & $\begin{array}{c}34.81 \\
(36.13)\end{array}$ & $\begin{array}{c}39.58 \\
(38.96)\end{array}$ & $\begin{array}{c}44.68 \\
(41.93)\end{array}$ & $\begin{array}{c}34.90 \\
(36.28)\end{array}$ & $\begin{array}{c}38.49 \\
(38.30)\end{array}$ & 84.59 \\
\hline $\begin{array}{l}\text { GLE of Anthemous } \\
\text { cotula } 5 \%\end{array}$ & $\begin{array}{c}27.62 \\
(31.68)\end{array}$ & $\begin{array}{c}31.38 \\
(34.05)\end{array}$ & $\begin{array}{c}35.15 \\
(36.34)\end{array}$ & $\begin{array}{c}28.87 \\
(32.48)\end{array}$ & $\begin{array}{c}30.75 \\
(33.64)\end{array}$ & 80.71 \\
\hline GLE Datura5\% & $\begin{array}{c}23.41 \\
(28.92)\end{array}$ & $\begin{array}{c}35.72 \\
(36.63)\end{array}$ & $\begin{array}{c}28.63 \\
(32.33)\end{array}$ & $\begin{array}{c}26.14 \\
(30.73)\end{array}$ & $\begin{array}{c}28.47 \\
(32.15)\end{array}$ & 79.17 \\
\hline GLE Walnut 5\% & $\begin{array}{c}14.44 \\
(22.30)\end{array}$ & $\begin{array}{c}27.54 \\
(31.64)\end{array}$ & $\begin{array}{l}20.09 \\
(26.61)\end{array}$ & $\begin{array}{c}16.53 \\
(23.97)\end{array}$ & $\begin{array}{c}19.65 \\
(26.13) \\
\end{array}$ & 69.82 \\
\hline NSKE @ 5\% & $\begin{array}{c}39.90 \\
(39.14)\end{array}$ & $\begin{array}{c}49.18 \\
(44.51)\end{array}$ & $\begin{array}{c}59.02 \\
(50.17)\end{array}$ & $\begin{array}{c}38.53 \\
(38.35)\end{array}$ & $\begin{array}{c}46.65 \\
(43.04)\end{array}$ & 87.28 \\
\hline Ginger Extract5\% & $\begin{array}{c}17.17 \\
(24.46)\end{array}$ & $\begin{array}{c}32.62 \\
(34.80)\end{array}$ & $\begin{array}{l}25.75 \\
(30.47)\end{array}$ & $\begin{array}{l}21.89 \\
(27.87)\end{array}$ & $\begin{array}{c}24.35 \\
(29.40)\end{array}$ & 75.64 \\
\hline $\begin{array}{l}\text { Dichlorvos 76 EC @ } \\
0.076 \%\end{array}$ & $\begin{array}{c}48.15 \\
(43.92)\end{array}$ & $\begin{array}{c}59.11 \\
(50.23)\end{array}$ & $\begin{array}{c}69.23 \\
(56.29)\end{array}$ & $\begin{array}{l}46.16 \\
(62.77)\end{array}$ & $\begin{array}{c}55.66 \\
(48.30)\end{array}$ & 89.34 \\
\hline Untreated (water) & $\begin{array}{c}3.78 \\
(11.10)\end{array}$ & $\begin{array}{c}9.20 \\
(17.64)\end{array}$ & $\begin{array}{c}5.98 \\
(14.09)\end{array}$ & $\begin{array}{c}4.78 \\
(12.56)\end{array}$ & $\begin{array}{c}5.93 \\
(13.85)\end{array}$ & - \\
\hline Mean & $\begin{array}{l}26.16 \\
(29.71)\end{array}$ & $\begin{array}{c}35.54 \\
(36.06)\end{array}$ & $\begin{array}{l}36.06 \\
(36.03)\end{array}$ & $\begin{array}{c}27.22 \\
(30.61)\end{array}$ & - & - \\
\hline$C D_{(P \leq 0.05)}$ & 2.11 & 3.00 & 1.60 & 1.68 & & \\
\hline Treatment & 1.08 & & & & & \\
\hline Days & 0.76 & & & & & \\
\hline Treatment $\times$ Days & 2.16 & & & & & \\
\hline
\end{tabular}


Fig.1 Efficacy of various botanicals and DDVP against Mythimna separata

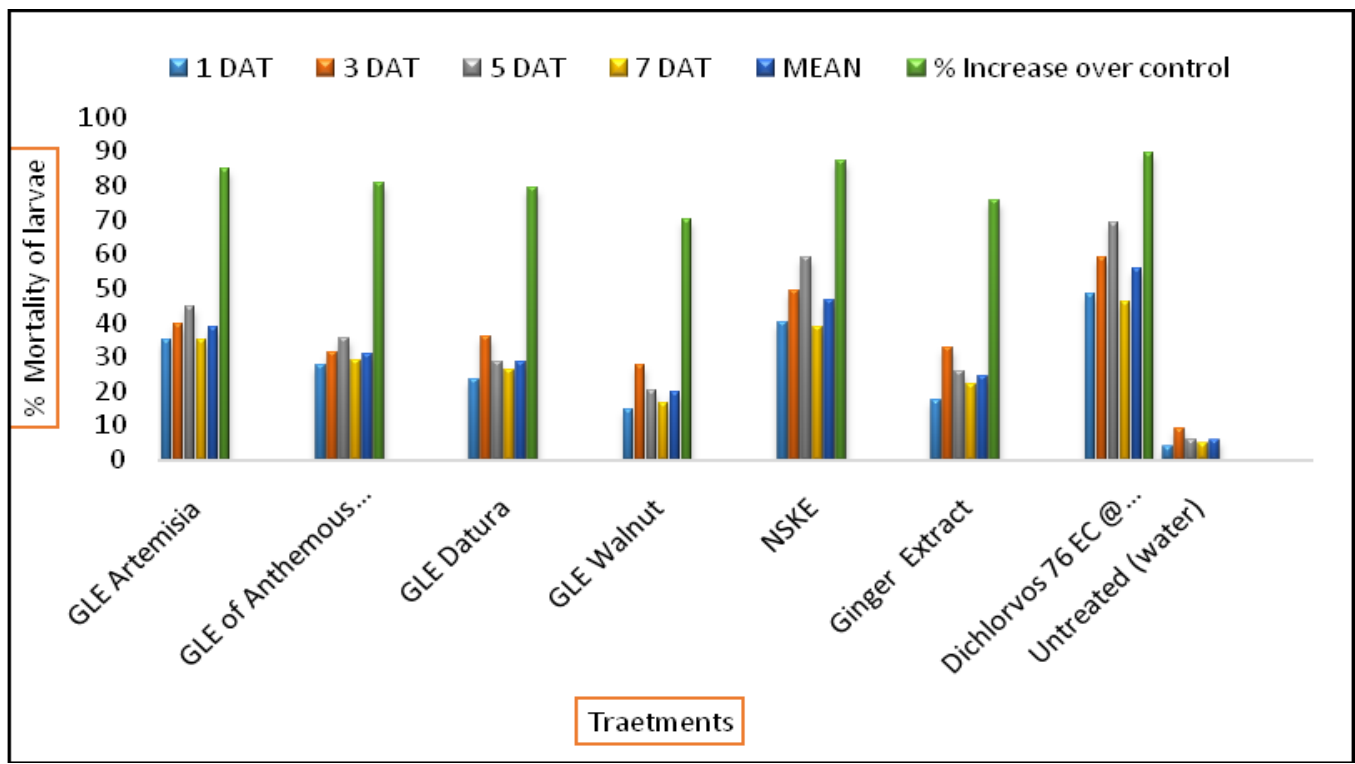

Abbasipour et al., (2011b), reported that the seed and leaves extract of $D$. stramonium also used to control of Tribolium castaneum. They also reported that with the increase in concentration, mortality of adults also increased, and the highest mortality was seen at a concentration of $5000 \mathrm{mg} \mathrm{L}^{-1}$. LC50 and LC90 values for $T$. castaneum adults after $24 \mathrm{~h}$ of exposure to D. stramonium extract were 3936 and $15373 \mathrm{mg} \mathrm{L}^{-1}$, respectively. Botanical pesticides have many advantages over synthetic pesticides such as low mammalian toxicity, no risk of developing pest resistance, no adverse effect on plant growth, less expensive and easy availability, the botanical extracts may be utilized as an alternative to synthetic insecticides especially in organic cultivation. A potential reduction in costs of pest control through the use of botanicals encourages the farmers to produce black pepper in more ecofriendly ways and provides opportunities for attracting special price premiums on the international market. Generally, the Oats crop is harvested during July and the population of $M$. separata increases during the subsequent summer months. Hence, adoption of control measures needs to be initiated after crop harvest which is also safer. The results obtained in the present investigation can very well be utilized as alternative to synthetic insecticides for the management of $M$. separata on oats.

The use of plant extracts with insecticidal properties has the potential of reducing the effects of insect pests of agricultural crops. These can be of importance to the resourcepoor farmers in many areas of the developing world. The significant reduction in pest's numbers on the treated plants was an indication that they can be used as alternatives to chemical insecticides. Even though various pest species attacked the oats crop, $M$. separata caused the most serious damage. It was the main cause of reduction of loss of fodder as well as grain.

\section{References}

Abbasipour, H., Mahmoudvand, M., Rastegar, F., Hosseinpour, M.H. 2011(b). Bioactivities of jimson weed extract, Datura stramonium L. (Solanaceae), against Tribolium castaneum (Coleoptera: Tenebrionidae). Turkish Journal of Agriculture and Forestry, 35(6): 623-9. 
Abd-Elhady, H., 2012. Insecticidal activity and chemical composition of essential oil from Artemisia judaica L. against Callosobruchus maculatus (F.) (Coleoptera: Bruchidae), Journal of Plant Protection Research, 52(3): 347-352.

Ahmad, M. and Zaffar, G. 2014. Evaluation of oats (Avena sativa L.) genotypes for betaglucan, grain yield and physiological traits. Applied Biological Research,16(1):1-3.

Bale, J.S., Van Lenteren, J.C. and Bigler, F., 2008. Biological control and sustainable food production. Philosophical Transactions of the Royal Society of London B: Biological Sciences, 363(1492): 761-776.

Calvo, D. and Molina, J.M. 2003. Effects of a commercial Neem (Azadirachta indica) extract on streblote panda larvae. Phytoparas, 31: 365-370.

Gomez, K.A. and Gomez, A.A. 1984.Statistical Procedures for Agricultural Research. An International Rice Research Institute. 2nd edition. Wiley-Inter Science Publication, New York. Pp. 680.

Hellpap, C., 1984. Effects of neem kernel extracts on the fall armyworm, Spodoptera fruqiperda. In: Natural pesticides from the neem tree (Azadirachta indica A. Juss) and other tropical plants $(\mathrm{H}$. Schmutterer and K.R.S. Ascher). Proceeding Third International Neem Conference, German Agency for Technological Cooperation, Berlin, Germany. Pp. 353-364.

Indiati, S.W. and Suharsono, B. 2013. Effect applications of neem seed powder, Spodoptera litura Nuclear Polyhedrosis Virus (SlNPV), and Resistant Variety to the Development of Armyworm on Soybean. Food Crops Research, 32:43-49.

Khosravi, R., Jalali Sendi, J. and Ghadamyari, M.
2010. Effect of Artemisia annua L. on deterrence and nutritional efficiency of lesser mulberry pyralid (Glyphodes pylolais Walker) (Lepidoptera: Pyralidae). Journal of Plant Protection Research, 50(4): 423428.

Koul, O. and Walia, S., 2009. Comparing impacts of plant extracts and pure allele chemicals and implications for pest control. $C A B$ Reviews: Perspectives in Agriculture, Veterinary Science, Nutrition and Natural Resources, 4(049): 1-30.

Lone, G.M., Baba, Z. A., Wani, N. A., Mir, S. A., Malik, M. A. and Parveena, B. 2009. Determination of pest complex of oats Avena sativa (L.) var. Kent and their status. Indian Journal of Applied Entomology,23(2): 140-144.

Pandey, K.C. and Roy, A.K. 2011. Forage Crops Varieties. IGFRI Jhansi (India) Pp. 16-17.

Schmutterer, H. and Singh, R.P. 1995. List of insect pest susceptible to neem products In: Schmutterer H (Ed.), The Neem TreeSource of Unique Natural products for Integrated Pest Management, Medicine, Industry and Other Purposes., $\mathrm{VCH}$, Weinheim, New York, Basel, Cambridge, Tokyo. Pp. 326-365.

Southwood, T.R.E. and G.A. Norton. 1973. Economic aspects of pest management strategies and decisions. Pp. 168-184. In: P.W. Geier et al., (ed.) Insects: Studies in population management. Ecological Society of Australia, Canberra, Australia.

Walkden, H.H. 1950. Cutworms, armyworms and related species attacking cereal and forage crops in the Central Great Plains. USDA Circular. 849. U.S. Government Printing Office, Washington, DC.

\section{How to cite this article:}

Ritesh Kumar, Ishtiyaq Ahad, Aijaz Ahmad Sheikh, Abid Showkat, Uzma Arifie and Stanzin Dorjey. 2017. Bioactive Plant Extracts an Alternate to Chemicals for Management of Armyworm Infesting Oats. Int.J.Curr.Microbiol.App.Sci. 6(12): 129-134.

doi: https://doi.org/10.20546/ijcmas.2017.612.017 